\title{
PEMBERDAYAAN KELOMPOK WANITA TANI MELALUI OPTIMALISASI PEMANFAATAN PEKARANGAN DENGAN BUDIDAYA SAYURAN ORGANIK DATARAN RENDAH BERBASIS KEARIFAN LOKAL DAN BERKELANJUTAN
}

\author{
EMPOWERMENT OF WOMEN FARMER GROUPS THROUGH \\ OPTIMALIZATION OF GARDEN UTILIZATION WITH ORGANIC \\ VEGETABLES IN LOW LAND BASED ON LOCAL AND SUSTAINABLE \\ ${ }^{1)}$ Endang Warih Minarni, ${ }^{2)}$ Darini Sri Utami, ${ }^{3)}$ Nur Prihatiningsih \\ ${ }^{123}$ Fakultas Pertanian, Universitas Jenderal Soedirman \\ Jl. Dr. Suparno, Karangwangkal, Purwokerto \\ 1)email: endangwarihminarni@gmail.com
}

\begin{abstract}
ABSTRAK
Tujuan khusus kegiatan KKN-PPM ini adalah meningkatkan motivasi wanita dalam memperbaiki kualitas hidup dan kemandirian dalam keluarga dengan mengoptimalisasikan pekarangan dengan budidaya sayuran organik dataran rendah berbasis Kearifan Lokal dan Berkelanjutan. Strategi yang digunakan adalah pemberdayaan kelompok sasaran dengan pendekatan Partisipatory Rural Appraisal, metode pendidikan, pelatihan, demplot, pendampingan serta dilengkapi dengan teknik belajar sambil bekerja (learning by doing). Materi yang disampaikan adalah: (1) teknologi intensifikasi lahan dengan metode vertikultur, (2) teknologi budidaya sayuran organik berbasis POC, pestisida nabati serta PGPR, (3) teknologi pembuatan kompos dengan pengayaan agens hayati Trichoderma harzianum (Tricho-kompos) dengan aktivator mikroorganisme lokal, (4) teknologi pengendalian hama dan penyakit pada tanaman sayuran secara ramah lingkungan dengan menggunakan insektisida nabati dan mikroba antagonis, (5) teknologi efisiensi penggunaan air dengan irigasi tetes, (6) teknologi sortir, grading dan packing yang baik, (7) teknologi pemberdayaan untuk membentuk kelompok dan penguatan kelembagaan dan manajemen kelompok. Hasil dari kegiatan ini adalah: (1) kelompok sasaran/anggota KWT memiliki rasa ingin tahu yang sangat tinggi terhadap informasi baru yang dapat meningkatkan taraf hidup mereka, (2) kegiatan alih teknologi pemanfaatan pekarangan dengan budidaya sayuran organik mendapat tanggapan yang positif dari anggota KWT, (3) Kegiatan pengabdian ini dapat mendorong pola pikir dan pola tindak anggota KWT dalam budidaya sayuran organik dengan mengembangan sumberdaya pedesaan dan kearifan lokal berkelanjutan, (4) Teknik budidaya verikultur dengan tipe paralon tegak dengan luas lahan $10 \mathrm{~m}^{2}$ secara ekonomis menguntungkan
\end{abstract}

Kata Kunci : Sayuran organik, vertikultur, Trichoderma harzianum,

\section{ABSTRACT}

The specific purpose of this activity is to increase the motivation of women in improving the quality of life and self-reliance in the family by optimizing the yard with organic vegetable farming in the lowlands based on Local Wisdom and Sustainable. The strategy used was the empowerment of target groups with the approach of Participatory Rural Appraisal, methods of education, training, demonstration plots, assistance and equipped with learning by doing techniques. The materials presented were: (1) garden intensification technology with verticultur method, (2) organic vegetable cultivation technology based on liquid organic fertilizer, botanical pesticide and PGPR, (3) composting technology with enrichment of Trichoderma harzianum (Tricho-compos) activator of local microorganism, (4) technology of pest and disease control on environmentally friendly vegetable crops using botanical insecticides and microbial antagonists; (5) water use efficiency technology with drip irrigation; (6) good sorting, grading and packing technology, 7) empowerment technology to form groups and institutional strengthening and group management. The results of this activity are: (1) the target group / 
members The women farmer group has a very high curiosity about new information that can improve their standard of living,(2) technology transfer activities on the use of garden with organic vegetable cultivation received positive response from the members of the Group, (3) This devotional activity can encourage the pattern of mind and pattern of member action in organic vegetable cultivation by developing rural resources and sustainable local wisdom, (4) Verikultur cultivation technique with vertical paralon type on a land area of $10 \mathrm{~m} 2$ is economically profitable

Keywords: Organic Vegetables, vertikultur, Trichoderma harzianum

Submited : 10 Mei 2017 Revision : 30 Juli 2017 Accepted : 16 September 2017

\section{PENDAHULUAN}

Pemberdayaan merupakan konsep alternatif untuk meningkatkan kemampuan dan martabat masyarakat agar terlepas dari jerat kemiskinan dan keterbelakangan. Atau, dengan kata lain, menjadikannya "berpower" atau memandirikan dan memampukan masyarakat(Kartasasmita, 1996).Dalam konsepsi ini Kartasasmita mengajukan beberapa pendekatan dalam upaya pemberdayaan masyarakat, yaitu, pertama, menciptakan suasana atau iklim yang memungkinkan potensi masyarakat berkembang (enabling). Pemberdayaan adalah upaya membangun daya itu dengan mendorong, memotivasi dan membangkitkan kesadaran akan potensi yang dimilikinya serta berupaya mengembangkannya. Kedua, memperkuat potensi atau daya yang dimiliki oleh masyarakat (empowering). Dalam rangka ini diperlukan langkah-langkah lebih konkret, selain menciptakan "atmosfer" bagi bekerjanya pemberdayaan, juga menyangkut penyediaan berbagai masukan (input), serta pembukaan akses ke dalam berbagai peluang (opportunities) yang akan membuat masyarakat menjadi makin berdaya. Ketiga, makna melindungi, yakni melindungi masyarakat yang lemah (kurang berdaya dalam menghadapi yang kuat) (Kuswandoro,2016). Pada hakekatnya, pemberdayaan merupakan suatu kegiatan yang lebih menekankan kepada proses, sehingga partisipasi atau keterlibatan masyarakat dalam setiap tahapan pemberdayaan mutlak diperlukan

Pemberdayaan wanita di Kecamatan Kebasen melalui optimalisasi pemanfaatan pekarangandengan budidaya sayuran organik merupakan salah satu usaha untuk dapat meningkatkan pendapatan keluarga sehingga terjadi peningkatan kualitas hidup dan kemandirian wanita. Berdasarkan hasil analisis situasi diketahui bahwa jumlah penduduk wanita di Kecamatan Kebasen mencapai 49,67 \% persen dari jumlah penduduk (28.442 orang). Besarnya jumlah penduduk wanita merupakan salah satu potensi desa yang dapat dikembangkan untuk meningkatkan taraf hidup keluarga. Salah satu sumber daya alam yang dapat dimanfaatkan adalah lahan pekarangan dan kebun seluas2.756,19 hektar (Monografi Kecamatan Kebasen, 2016).Selama ini, masyarakat masih belum memanfaatkan lahan pekarangan secara optimal. Masyarakat umumnya memanfaatkan pekarangan dengan menanam tanaman kelapa dan buah-buahan seperti pisang, mangga, rambutan, dan lain-lain yang mana hasilnya hanya dapat diperoleh setahun sekali pada musim panen. Sedangkan pada musim panen harga dari buah-buahan tersebut rendah. Selain itu keberadaan tanaman tersebut dibiarkan tumbuh tanpa ada pemeliharaan yang baik.sehingga hasilnya juga tidak optimal. 
Pertanian organik merupakan jawaban atas revolusi hijau yang digalakkan pada tahun 1960-an yang menyebabkan berkurangnya kesuburan tanah dan kerusakan lingkungan akibat pemakaian pupuk dan pestisida kimia yang tidak terkendali. Sistem pertanian berbasis high input energy seperti pupuk kimia dan pestisida dapat merusak tanah yang akhirnya dapat menurunkan produktifitas tanah, sehingga berkembang pertanian organik. Pertanian organik sebenarnya sudah sejak lama dikenal, sejak ilmu bercocok tanam dikenal manusia, semuanya dilakukan secara tradisional dan menggunakan bahan-bahan alamiah. Pertanian organik modern didefinisikan sebagai sistem budidaya pertanian yang mengandalkan bahan-bahan alami tanpa menggunakan bahan kimia sintetis. Pengelolaan pertanian organik didasarkan pada prinsip kesehatan, ekologi, keadilan, dan perlindungan. Prinsip kesehatan dalam pertanian organik adalah kegiatan pertanian harus memperhatikan kelestarian dan peningkatan kesehatan tanah, tanaman, hewan, bumi, dan manusia sebagai satu kesatuan karena semua komponen tersebut saling berhubungan dan tidak terpisahkan (Mayrowani, 2012)

Pendekatan holistik untuk mengoptimalkan produktivitas lahan pekarangan secara nyata dapat dilakukan dengan mensinergikan kekuatan sumberdaya alam berbasis kearifan lokaldan berkelanjutan yang terencana dengan baik. Salah satu teknologi berbasis kearifan lokal dan berkelanjutan dapat melalui pendekatan sistem produksi yang holistik dan terencana yaitu budidaya sayuran organik. Pertanian organik menitikberatkan pada pemanfaatan kekuatan biologis tanah, pengelolaan tanaman, pemupukan dan tataguna air secara organik dan terencana untuk mendukung pertumbuhan dan produksi tanaman sayuran.
Budidaya sayuran organik menjadi pilihan utama untuk dikembangkan karena dapat menyediakan sayuran yang sehat bagi keluarga, teknik pemeliharaannya relatif mudah, dan mempunyai nilai ekonomis yang tinggi Mahalnya sayuran organik salah satunya disebabkan karena produk yang dihasilkan aman untuk dikonsumsi, jumlah produsennya yang sangat terbatas dan resiko kegagalan yang tinggi, sehingga menjadi produk eksklusif.

\section{METODE}

Metode yang digunakan dalam pelaksanaan kegiatan KKN PPM ini adalah untuk peningkatan pengetahuan dan ketrampilan petani dengan metode alih teknologi dan pembuatan demplot (percontohan) sertapendampingan dengan pendekatan Partisipatory Rural Appraisal (PRA), yakni merupakan pendekatan dalam merumuskan perencanaan dan kebijakan di wilayah pedesaan dengan cara melibatkan masyarakat seefektif mungkin, (Chambers, 1994).Metode PRA dikembangkan dengan alasan: (1) menyelenggarakan kegiatan bersama masyarakat untuk mengupayakan pemenuhan kebutuhan praktis dan peningkatan kesejahteraan masyarakat dan sekaligus sebagai sarana proses belajar, (2) dapat membawa visi untuk mencapai pemberdayaan masyarakat dan perubahan sosial melalui pengembangan masyarakat dengan menggunakan pendekatan pembelajaran, (3) para petani dapat secara langsung berdiskusi dan melihat contoh hasil kegiatan.

Tingkatan partisipasi masyarakat ini tercapai apabila pengorganisasian masyarakat mengarah ke tahapan pembebasan diri sampai kepada tingkat partisipasi mandiri (self mobilization). Teknik pelaksanaan yang dilakukan adalah pendidikan, pendampingan dan demplot 
yang dilengkapi dengan teknik belajar sambil bekerja (learning by doing).

\section{HASIL DAN PEMBAHASAN}

Indiator keberhasilan dari kegiatan KKN PPM dapat diketahui dengan membandingkan kondisi awal sebelum kegiatan dan capaian yang diperoleh setelah kegiatan. Tabel 1 menunjukkan bahwa pelaksanaan KKN di Desa Tumiyang, Gambarsari, Cindaga, Kalisalak, Sawangan, Adisana Kecamatan Kebasen Kabupaten Banyumas ini mendapat sambutan yang baik dari masyarakat. Keberhasilan ini merupakan hasil kerjasama dari para anggota kelompok wanita tani, perangkat desa, masyarakat, mahasiswa KKN, DPL dan tim pelaksana kegiatan ini.

Kegiatan yang diprogramkan dalam KKN-PPM dapat diselesaikan dalam waktu yang ditentukan dan respon dari khalayak sangat baik. Hasil wawancara dengan anggota kelompok wanita tani menunjukkan bahwa kegiatan yang dilakukan merupakan hal yang baru dan mereka tertarik untuk mempelajari dan mempraktikan. Bahkan mereka dengan swadaya mendukung kegiatan KKN.
Pembuatan vertikultur paralon tegak dan vertikultur dengan sistem irigasi tetes memotivasi khalayak sasaran untuk memanfaatkan pekarangannya dengan budidaya tanaman sayuran organik. Selain untuk persediaan sayuran keluarga juga dimanfaatkan untuk keindahan lingkungan.

Keberhasilan KKN PPM di Kecamatan Kebasen ini, merupakan wujud dari partisipasi masyarakat. Partisipasi masyarakat menurut Adi (2007) adalah keikutsertaan masyarakat dalam proses pengidentifikasian masalah dan potensi yang ada di masyarakat, pemilihan dan pengambilan keputusan tentang alternatif solusi untuk menangani masalah, pelaksanaan upaya mengatasi masalah, dan keterlibatan masyarakat dalam proses mengevaluasi perubahan yang terjadi.

Indikator keberhasilan dapat dilihat dalam tabel berikut :

Tabel 1. Indikator keberhasilan dan capaian program KKN PPM

\begin{tabular}{|c|c|c|c|c|c|}
\hline Kegiatan & Indikator & $\begin{array}{l}\text { Sebelum } \\
\text { KKN }\end{array}$ & Target & $\begin{array}{l}\text { Setelah } \\
\text { KKN }\end{array}$ & $\begin{array}{l}\text { Capaian } \\
(\%)\end{array}$ \\
\hline $\begin{array}{l}\text { Intensifikasi lahan } \\
\text { pekarangan dengan } \\
\text { metode vertikultur. }\end{array}$ & $\begin{array}{l}\text { Adanya khalayak sasaran yang } \\
\text { menerapkan metode budidaya } \\
\text { sayuran organik secara vertikultur }\end{array}$ & 0 & 120 & 158 & 131,7 \\
\hline $\begin{array}{l}\text { Intensifikasi lahan } \\
\text { pekarangan dengan } \\
\text { menanam sayuran } \\
\text { dalam polibag }\end{array}$ & $\begin{array}{l}\text { Adanya khalayak sasaran yang } \\
\text { menerapkan metode budidaya } \\
\text { sayuran organik secara vertikultur }\end{array}$ & 0 & 3000 & 3500 & 116,7 \\
\hline $\begin{array}{l}\text { Pembuatan pupuk } \\
\text { organik cair, pestisida } \\
\text { nabati serta PGPR } \\
\text { (Plant Growth } \\
\text { Promoting }\end{array}$ & $\begin{array}{l}\text { Adanya khalayak sasaran yang } \\
\text { mampu dan terampil membuat } \\
\text { pupuk organik cair, pestisida } \\
\text { nabati dan PGPR dalam budidaya } \\
\text { sayuran organik }\end{array}$ & 0 & 18 & 18 & 100,0 \\
\hline
\end{tabular}


Endang Warih Minarni, Darini Sri Utami, Nur Prihatiningsih

Pemberdayaan Kelompok Wanita Tani Melalui Optimalisasi Pemanfaatan Pekarangan dengan Budidaya Sayuran Organik Dataran Rendah Berbasis Kearifan Lokal dan Berkelanjutan

\begin{tabular}{|c|c|c|c|c|c|}
\hline \multirow{2}{*}{\multicolumn{2}{|c|}{ Rhizobacterium) }} & & & & \\
\hline & & & & & \\
\hline $\begin{array}{l}\text { Pembuatan kompos } \\
\text { dengan pengayaan } \\
\text { agens hayati } \\
\text { Trichoderma } \\
\text { harzianum (Tricho- } \\
\text { kompos) dengan } \\
\text { aktivator } \\
\text { mikroorganisme lokal }\end{array}$ & $\begin{array}{l}\text { Adanya khalayak sasaran yang } \\
\text { mampu dan terampil membuat } \\
\text { kompos dengan pengayaan } \\
\text { Trichoderma harzianum dengan } \\
\text { aktivitas mikroorganisme lokal }\end{array}$ & 0 & 18 & 18 & 100,0 \\
\hline $\begin{array}{l}\text { Pengendalian hama dan } \\
\text { penyakit pada tanaman } \\
\text { sayuran secara ramah } \\
\text { lingkungan dengan } \\
\text { menggunakan musuh } \\
\text { alami }\end{array}$ & $\begin{array}{l}\text { Adanya khalayak sasaran yang } \\
\text { mampu dan terampil } \\
\text { memperbanyak parasitoid dan } \\
\text { predator }\end{array}$ & 0 & 18 & 18 & 100,0 \\
\hline $\begin{array}{l}\text { Teknologi efisiensi } \\
\text { penggunaan air dengan } \\
\text { irigasi tetes }\end{array}$ & $\begin{array}{l}\text { Adanya khalayak sasaran yang } \\
\text { mampu dan terampil membuat } \\
\text { instalasi irigasi tetes untuk } \\
\text { budidaya sayuran organik secara } \\
\text { vertikultur }\end{array}$ & 0 & 18 & 18 & 100,0 \\
\hline $\begin{array}{l}\text { Teknologi sortir, } \\
\text { grading dan packing } \\
\text { yang baik. }\end{array}$ & $\begin{array}{l}\text { Adanya khalayak sasaran yang } \\
\text { mampu dan terampil dalam } \\
\text { menyortir, grading dan packing } \\
\text { yang baik }\end{array}$ & 0 & 18 & 18 & 100,0 \\
\hline Teknik pemasaran hasil & $\begin{array}{l}\text { Adanya khalayak sasaran yang } \\
\text { mampu dan terampil dalam } \\
\text { memasarkan hasil }\end{array}$ & 0 & 18 & 18 & 100,0 \\
\hline $\begin{array}{l}\text { Pengelolaan } \\
\text { Lingkungan dan } \\
\text { kesehatan masyarakat }\end{array}$ & $\begin{array}{l}\text { Adanya khalayak sasaran yang } \\
\text { mampu dan terampil dalam } \\
\text { mengelola lingkungan }\end{array}$ & 0 & 18 & 18 & 100,0 \\
\hline $\begin{array}{l}\text { Pemberdayaan } \\
\text { kelompok dan } \\
\text { penguatan } \\
\text { kelembagaan serta } \\
\text { manajemen kelompok }\end{array}$ & $\begin{array}{l}\text { Adanya khalayak sasaran yang } \\
\text { bertanggungjawab terhadap } \\
\text { kegiatan kelompok. }\end{array}$ & 0 & 18 & 18 & 100,0 \\
\hline
\end{tabular}

Dalam kegiatan budidaya, khalayak sasaran juga mencoba untuk membandingkan poduksi beberapa sayuran organik pada tiga tipe budidaya secara vertikutur yaitu dengan paralon tegak, paralon susun dengan irigasi tetes dan polibag pada rak bertingkat. Bobot basah sayuran organik yang dibudidayakan untuk 3 tipe vertikultur disajikan pada Tabel 2 . 
Tabel 2. Bobot basah kangkung,caisin, selada dan bayam per $\mathrm{m}^{2}$ pada tiga tipe vertikultur

\begin{tabular}{|c|c|c|c|c|c|}
\hline Tipe & $\begin{array}{c}\text { Jumlah lubang } \\
\text { tanam } / \mathrm{m} 2\end{array}$ & Kangkung (g) & Caisin (g) & Selada (g) & Bayam (g) \\
\hline Paralon tegak & 180 & 720 & 4140 & 8.640 & 2,520 \\
\hline $\begin{array}{ll}\text { Paralon } & \text { susun } \\
\text { dengan } & \text { irigasi } \\
\text { tetes } & \end{array}$ & 42 & 252 & 1.050 & 2.520 & 798 \\
\hline $\begin{array}{l}\text { Polibag pada } \\
\text { rak bertingkat }\end{array}$ & 16 & $\begin{array}{c}245 \\
\text { (1 polibag } \\
5 \text { tanaman) }\end{array}$ & 656 & 1.296 & $\begin{array}{c}1,440 \\
\text { (1 polibag } 3 \\
\text { tanaman }\end{array}$ \\
\hline
\end{tabular}

Sistem pertanian vertikultur adalah sistem budi daya pertanian yang dilakukan secara vertikal atau bertingkat (Sutarminingsih, 2003) . Sistem ini cocok diterapkan pada lahan sempit atau di pemukiman yang padat penduduknya. Budidaya tanaman sayuran secara vertikultur mempunyai kelebihan yaitu: efisiensi penggunaan lahan karena yang ditanam jumlahnya lebih banyak dibandingkan sistem konvensional, penghematan pemakaian pupuk dan pestisida, dan mempermudah pemeliharaan tanaman.

Berdasarkan Tabel 2 diketahui bahwa pada luasan yang sama yaitu $1 \mathrm{~m}^{2}$ penanaman dengan paralon tegak lebih efisien. Dengan luasan yang sama jumlah tanaman yang ditanam lebih banyak dan bobot basah dari sayuran lebih tinggi dibanding pada paralon susun dengan irigasi tetes dan polibag pada rak bertingkat.

Namun untuk penggunaan paralon bertingkat dengan irigasi tetes mempunyai kelebihan yaitu dalam pemeliharaan. Penyiraman dan pemupukan dapat lebih mudah dilakukan. Penyiraman tidak perlu dilakukan setiap hari. Pupuk juga dapat dilarutkan dalam air yang digunakan untuk penyiraman.Jaringan irigasi tetes ini berfungsi untuk menghemat air sesuai kebutuhan tanaman dengan hasil produksi sayuran yang tidak kalah dengan penyiraman sistem genang atau kocor di lahan. Pengairan di dalam rak vertikultur untuk tanaman sayuran daun dilakukan bila tanah di sekitar tanaman sudah kering

(hidrologis) Biasanya hampir setiap hari petani/pengguna teknologi menyiram tanaman. Bila untukmengefisienkan tenaga, maka pengairan dapat dilakukan dua hari sekali dengan volume air kapasitas lapang (tanah dalam keadaan basah) (Setiapermas dan Zamawi, 2017)

Sayuran organik secara ekonomis mempunyai harga yang lebih tinggi dibandingkan harga sayuran non organik. Harga sayuran organik di beberapa supermarket di Kabupaten Banyumas untuk kangkung dan bayam sekitar $\mathrm{Rp}$ 6.000/250 gr sedangkan untuk Caisin dan Selada sekitar Rp 8.000/250 gr. Berdasarkan harga tersebut, dapat dihitung seberapa besar harga jual yang diterima oleh petani. Secara ekonomis untuk luasan $1 \mathrm{~m}^{2}$ tipe vertikal paralon tegak lebih menguntungkan, meskipun bobot per tanaman lebih kecil namun karena jumlah tanamannya lebih banyak maka bobot secara keseluruhan lebih besar. Lebih jelasnya dapat dilihat dalam tabel berikut : 
Tabel 3. Harga jual sayuran organik yang dibudidayakan untuk 3 tipe vertikultur per $\mathrm{m}^{2}$

\begin{tabular}{|c|c|c|c|c|c|}
\hline Tipe & $\begin{array}{c}\text { Jumlah lubang } \\
\text { tanam } / \mathrm{m} 2\end{array}$ & Kangkung (Rp) & Caisin (Rp) & Selada (Rp) & Bayam (Rp) \\
\hline Paralon tegak & 180 & 17.250 & 132.480 & 276.480 & 60.480 \\
\hline $\begin{array}{ll}\text { Paralon } & \text { susun } \\
\text { dengan } & \text { irigasi } \\
\text { tetes } & \\
& \end{array}$ & 42 & 6.048 & 33.600 & 80.000 & 19.008 \\
\hline $\begin{array}{l}\text { Polibag pada } \\
\text { rak bertingkat }\end{array}$ & 16 & 5.880 & 20.992 & 41.472 & 34.560 \\
\hline
\end{tabular}

Analisis usaha vertikultur tanaman selada dengan tiga tipe yang dilakukan di desa KKN dapat dilihat pada Tabel 4. Pada luas lahan $10 \mathrm{~m}^{2}$ dengan 7 kali tanam setahun tipe vertikultur paralon tegak secara ekonomis menguntungkan, susun dan polibag rak bertingkat tidak menguntungkan secara ekonomis. Kedua tipe tersebut lebih sesuai digunakan untuk konsumsi keluarga dan menambah keindahan lingkungan.

Tabel 4. Analisis usaha vertikultur tanaman selada

\begin{tabular}{|c|c|c|c|c|c|c|c|c|c|}
\hline & \multicolumn{3}{|c|}{ Pengeluaran } & \multicolumn{3}{|c|}{ Penjualan } & \multicolumn{3}{|c|}{ Pendapatan } \\
\hline & $\begin{array}{l}\text { Paralon } \\
\text { tegak }\end{array}$ & $\begin{array}{l}\text { Paralon } \\
\text { susun }\end{array}$ & Polibag & $\begin{array}{l}\text { Paralon } \\
\text { tegak }\end{array}$ & $\begin{array}{l}\text { Paralon } \\
\text { susun }\end{array}$ & Polibag & $\begin{array}{l}\text { Paralon } \\
\text { tegak }\end{array}$ & $\begin{array}{l}\text { Paralon } \\
\text { susun }\end{array}$ & Polibag \\
\hline Tempat tanam & 100.000 & 300.000 & 100.000 & & & & & & \\
\hline Bibit & 4.500 & 1.050 & 400 & & & & & & \\
\hline POC & 1.000 & 1.000 & 1.000 & & & & & & \\
\hline Pesnab & 1.000 & 1.000 & 1.000 & & & & & & \\
\hline Tenaga Kerja & 10.000 & 10.000 & 10.000 & & & & & & \\
\hline $1 \mathrm{~m} 2$ & 116.500 & 313.050 & 112.400 & 276.480 & 80.000 & 41.472 & & & \\
\hline $10 \mathrm{~m} 2$ & 1.165 .000 & 3.130 .500 & 1.124 .000 & 2.764 .800 & 800.000 & 414.720 & & & \\
\hline $\begin{array}{l}1 \text { tahun } \\
7 \text { kali tanam } \\
\end{array}$ & 8.155 .000 & 21.913 .500 & 7.868 .000 & 19.353 .600 & 5.600 .000 & 2.903 .040 & 11.198 .600 & 16.313 .500 & 4.964 .960 \\
\hline $\mathrm{BC}$ ratio & & & & & & & 1,373 & 0,00 & 0,00 \\
\hline
\end{tabular}

Berdasarkan uraian di atas dapat disimpulkan bahwa:

a. Anggota KWT di Desa Tumiyang, Gambarsari, Cindaga, Kalisalak, Sawangan dan Adisana Kecamatan Kebasen Kabupaten Banyumas memiliki rasa ingin tahu yang sangat tinggi terhadap informasi baru yang b. Kegiatan alih teknologi tentang teknologi pemanfaatan pekarangan dengan budidaya sayuran organik

mendapat tanggapan yang positif dari anggota KWT dan berjalan dengan baik dan lancar.

c. Kegiatan pengabdian ini dapat mendorong pola pikir dan pola tindak 
Endang Warih Minarni, Darini Sri Utami, Nur Prihatiningsih

Pemberdayaan Kelompok Wanita Tani Melalui Optimalisasi Pemanfaatan Pekarangan dengan Budidaya Sayuran Organik Dataran Rendah Berbasis Kearifan Lokal dan Berkelanjutan

anggota KWT dalam budidaya sayuran organik dengan mengembangan sumberdaya pedesaan dan kearifan lokal berkelanjutan.

d. Teknik budidaya verikultur dengan tipe paralon tegak dengan luas lahan $10 \mathrm{~m}^{2}$ secara ekonomis menguntungkan.

\section{DAFTAR PUSTAKA}

Adi, I. R. (2007). Perencanaan Partisipatoris Berbasis Aset Komunitas: dari Pemikiran Menuju Penerapan. Depok: FISIP UI Press.

Chambers, R. (1994). Participatory Rural Appraisal (PRA) : Analysis of Experience. World Development, 22 (9): 1253-1268.

Kartasasmita, G(1996). Pemberdayaan Masyarakat: Konsep Pembangunan Yang Berakar Pada Masyarakat. Makalah 14 Maret 1997

Kuswandoro W. E. 2016. Strategi Pemberdayaan Masyarakat Desa Berbasis Partisipasi (PDF Download Available). Available from:

https://www.researchgate.net/publi cation $\quad / 311101048$ Strategi_Pemberdayaan_Masyarak at_Desa_Berbasis_Partisipasi [accessed Oct 29 2017)

Mayrowani, H. (2012). Pengembangan Pertanian Organik Di Indonesia. Forum Penelitian Agro Ekonomi 30 (2): $91-108$.

Setiapermas, M.N. dan Zamawi. (2017). Pemanfaatan Jaringan Irigasi Tetes di dalam Budidaya Tanaman Hortikultura 271. Balai Pengkajian Teknologi Pertanian (BPTP) Jawa
Tengah .Inovasi Hortikultura

Pengungkit Peningkatan Pendapatan Rakyat. http://hortikultura.litbang.pertanian .go.id/Buku Inovasi/263-272. Meinarti\%20Norma\% 20Jaringan \%20Irigasi\%20tetes.pdf. Diakses 29 Oktober 2017.

Sutarminingsih, C.L. 2003. Vertikultur Pola Bertanam Secara Vertikal. Penerbit Kanisius. 102p. 